\title{
Forecasting towards Planning and Sustainable Development Based on a System Dynamic Approach: A Case Study of the Setiu District, State of Terengganu, Malaysia
}

\author{
Muhamad Safiih Lola1, Mohd Noor Afiq Ramlee1, Hanani Isa1, Mhd Ikhwanuddin Abdullah², \\ Mohd Fadli Hussin'1, Nurul Hila Zainuddin1, Mohd Naeim Rahman1
}

\footnotetext{
${ }^{1}$ School of Informatics and Applied Mathematics, University Malaysia Terengganu, Kuala Terengganu, Malaysia ${ }^{2}$ Institute Aquaculture Tropical, University Malaysia Terengganu, Kuala Terengganu, Malaysia Email: safiihmd@umt.edu.my, afiqramlee91@gmail.com, Hananiisa85@yahoo.com, ikhwanuddin@umt.edu.my, mohdfadlihussin@gmail.com, Hila.zainuddin@gmail.com, naeim89.nr@gmail.com
}

How to cite this paper: Lola, M.S., Ramlee, M.N.A., Isa, H., Abdullah, M.I., Hussin, M.F., Zainuddin, N.H. and Rahman, M.N. (2016) Forecasting towards Planning and Sustainable Development Based on a System Dynamic Approach: A Case Study of the Setiu District, State of Terengganu, Malaysia. Open Journal of Statistics, 6, 931-950. http://dx.doi.org/10.4236/ojs.2016.65077

Received: July 28, 2016

Accepted: October 24, 2016

Published: October 27, 2016

Copyright $\odot 2016$ by authors and Scientific Research Publishing Inc. This work is licensed under the Creative Commons Attribution International License (CC BY 4.0).

http://creativecommons.org/licenses/by/4.0/

\begin{abstract}
In this paper, a system dynamics approach is used instead of the traditional approaches to stimulate, forecast and analyze the economic effects of an existing policy practice in Setiu Wetland. As a part of Setiu district that uphold tradition in fishery and maritime based industry, Setiu Wetland area seems to be left behind in terms of economic and livelihood. Generally, Setiu development policy consists of five subsystem including population growth, economic, residential, transportation and suburban sprawl. Due to their widespread population distribution, Setiu Wetland receives low urban-related progress. Hence, a forecast of 30 years from 2016 to 2046 providing a necessary insight for potential development of the Setiu Wetland region, to simulate its environment, identify gaps, propose suitable land model towards Setiu Minapolitan area (Peri-urban area) and suggest directions for future studies particularly in economic and livelihood for local authorities to develop with.
\end{abstract}

\section{Keywords}

System Dynamics, Setiu Wetland, Minapolita, Economic and Livelihood, Policy Practice

\section{Introduction}

Setiu is one of the youngest from 8th districts in Terengganu. According to [1], Setiu region mainly involved agriculture, fisheries and marine based industries including 
tourism [1]-[3]. Setiu was formed on January 1st, 1985 due to certification of Administrative Modernization and Management Planning (MAMPU). This district has a total land area of $135,905.80$ hectares $\left(1359.90 \mathrm{~km}^{2}\right)$ of land or approximately $10.49 \%$ of Terengganu [1] [3]. A part of this 7th district of Terengganu, specifically the Setiu Wetland area could be called as a partial-Minapolitan concept-based region in Terengganu marine industries based on its performance in small maritime based industry (refer to Figure 1 [4] [5]). Setiu Wetlands also supplies between 50\% to $60 \%$ of Peninsular Malaysia's grouper (Ephinephelus spp) juveniles and oyster seeds, apart from constant supply of other marine products to comply the demand of National's and some of International usage [6]. [6] also suggests that the Setiu Wetland should not only develop economically, but also hold the potential of becoming the perfect choice to be Terengganu's first state park.

However the development of Setiu district still fell behind and the development plan was in disarray. Hence this study objective is to develop a development framework as a foothold for Setiu development plan in the future full consisting of economic

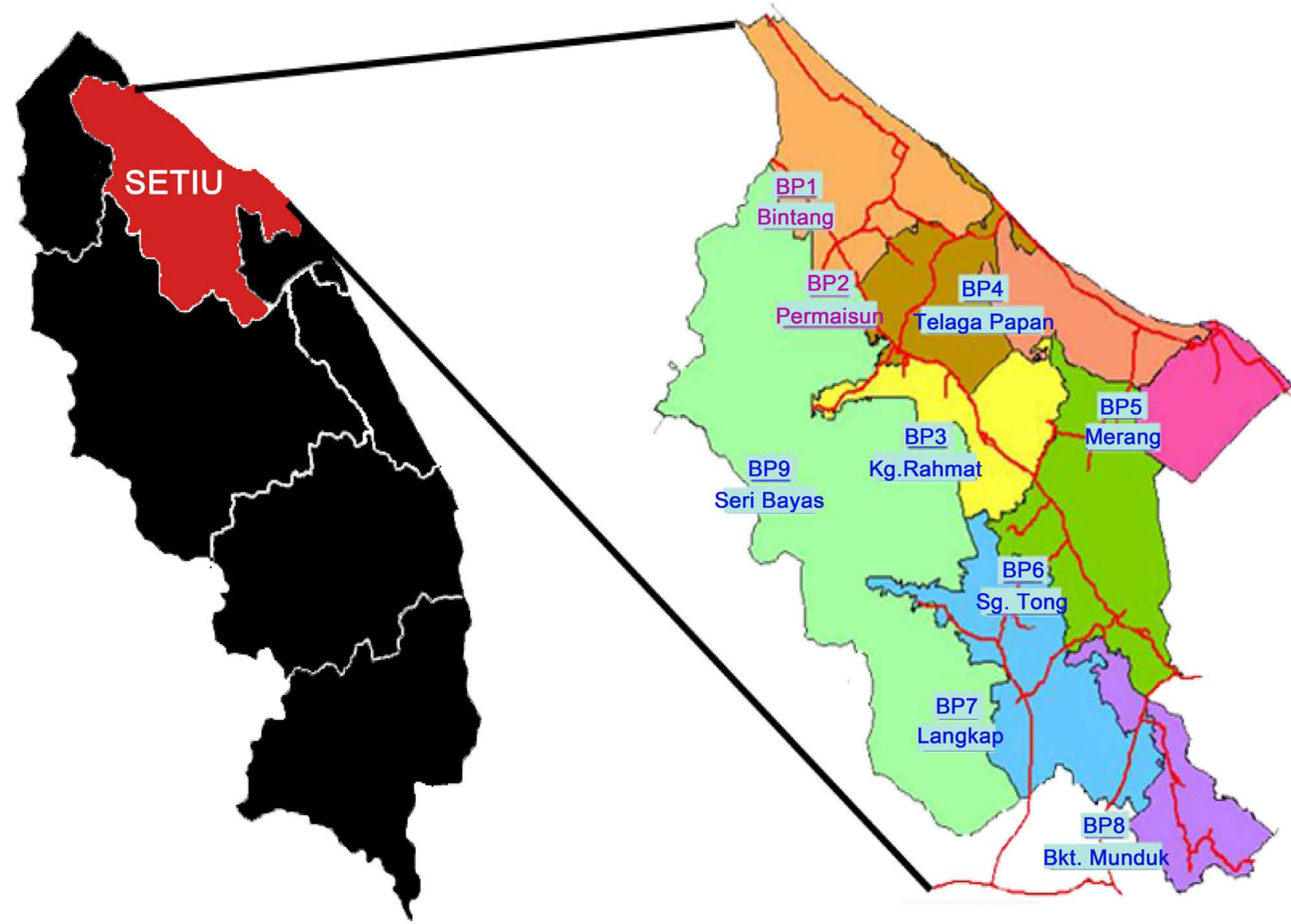

Figure 1. Setiu District Map. 
development for Terengganu Minapolitan area, and conservation development for other potential parts in Setiu Region. A fully Minapolitan concept-based region should rely on fisheries, aquaculture and marine commodities as much as their sea-based economic value [7] [8]. In order for Setiu to thrive in this current age, an economy boosts are needed to allow Setiu region to become a main supporter for Terengganu economic development in terms of aquaculture, agriculture and marine based industry [3] [9]. Setiu local population involvement in industry based business is still insufficient. Whether in aquaculture, tourism, small medium enterprise the major player in Setiu area comes from non-originated people or external investor [1] [9] [10]. Just like any other foodproducing sector in the world, aquaculture relies on renewable and non-renewable resources [11]. Hence, a sustainable development in overall livelihood and business canvas should be built and practiced in terms to uplift Setiu to become a fully cooperated Minapolitan without neglecting its environment and ecological surplus.

Setiu Wetlands harbors natural features comprising a diverse array of freshwater, brackish and marine ecosystems including unique habitats such as the Gelam forest and a 14-km lagoon stretching parallel to the coastline [6]. However, change in land use and reduced size of area as well as degradation of the different wetlands habitats which have occurred in the last few years are sending red alerts. Hence, there are many study regarding of Setiu Wetland on its threats, conservation, potential, and economic use. However, for the study that consists of Setiu district as whole are insufficient. Therefore the land dynamic study for Setiu district for promoting its sustainable development, growth and potential are indeed align with the demand of conserving and developing this particular area.

Viable land use is a notion derived from sustainable development, originated from the terms of Limits to Growth [12], that are extracted from Club of Rome Report which was published in 1972 and a notation from Forrester's System Dynamics modelling of Urban and Globe problems in Urban Dynamics [13]-[15]. In 2009, [15] has defined sustainable land use for Hong Kong development into a motion of been able to utilize land allocation/distribution efficiently to meet the needs of both present and future developments, socially, fulfilling the various requirement, such as employment, housing, transportation, etc. brought by a leaping of various sub-sectors into a prosperous and high quality development in various aspect. Hence, it could be concluded, for Setiu Pseudo-Minapolitan (development of rural to Peri-urban area) development to achieve sustainable viability, predefine that Setiu Wetland and costal area development should be consist a balance development in terms of preserving the natural resources and its scarcity, without neglecting the infrastructural development to allow Setiu to thrive as a fully functional Minapolitan area in future. This, of course, should include a well facilitated area that including housing with sanitation facility, full functional transportations, amenities and etc. that promote towards positive economic and livelihood growth [16].

Both local and international researcher from universities, government agency and NGO's take interest in sustainability issues in Setiu especially in the pseudo-minapolitan 
area such as Setiu Wetland and its surrounding area [2] [6] [17]. Different research regarding various policy implementation and its effect either completed or ongoing was being conducted in Setiu Wetland to evaluate its potential for future development. While certain scholar are focusing on certain specific issues, this research paper conducing an evaluation and modeling the whole region of Setiu Wetland to uncover its true potential and in hope to gain understanding for proposing development policies and strategies to cope with the objective above. Hence, the simulation that has been produced could be used to facilitate urban development of future Setiu Minapolitan for medium and long-term facelift.

\section{Objective of the Study}

The main objective of this study is to discuss an applicable dynamic approach for uplifting the economic and livelihood of Setiu District, while maintaining the core principle of conservation and preservation of natural resources and value. This study also attempted to estimate the potential development plan for uplift economic value of land, natural and work resources in the study area. Within the time frame of 30 years, starting from 2016 to 2046, do the different development plan can be used to develop Setiu District to become a full functional Minapoitan area without neglecting the core principle of sustainable development?

\section{System Dynamic Methodology}

In order to realize the forecasting, we need to develop a dynamic model using the system dynamic method to achieve full understanding of the study [3] [15] [18] [19]. As mentioned, we build a Minapolitan-Dynamics systems analysis model using a systems dynamics method that is originated from Professor Forrester of Massachusetts Institute of Technology in the mid-1950s [13] [20] [21]. After decades of development and improvement, the systemic dynamics model has been widely used in the study of economics, society, ecology and many complex systems [19] [22]. According to [23], System Dynamics has a few advantages, particularly in analyzing, improving and managing the system characterized through complex feedback effects as well as long development cycle. With this advantage and the requirement need in our study, the system dynamics method is used. This model development process was executed using Vinsim PLE for Windows Version 6.3D software developed by Ventana System, Inc.

It is essential to understand the behavior of the dynamic that should be created before proceeding to create a system model. Therefore, economic and livelihood dynamic must be related to a conceptual or logical framework in order to perform a full dynamic model [3] [16].

System dynamic basically made up by three variable; stock, rate and auxiliary, while flows have two; physical/material and information which could interact with each other [13] [15]. Together, variable and flow made up the basic structure of system dynamics. In system dynamics, simulation works entirely by passage of time referred as "timestep" simulation [15] [24] [25]. This overall process aims are to understand how and 
why the dynamic relation relates between policies or system towards its environmental effects. This policies or system refers to the long-term, macro-level decision rules used by upper management [15] [26].

\section{Model Description}

The time frame for this research are around 30 years, starting from 2016 to 2046 with slight conformation for prior to the Setiu District Local Plan (RSTD) proposed by Setiu District Council (MDS) and Director of Terengganu Town and [27]. The 30-year simulation time frame was chosen based on the adequate amount of time for new policy and development to form and produce significant changes [15].

Previously, we describe about the micro-level decision used by upper management, hence Figure 2 shows the relation of macro-management rules that used by previous research [15] [16] [18].

However, to understand the relation of macro-management of Setiu Pseudo- minapolitan and as well Setiu Wetland area, we need to alter in Figure 3 the diagram produce by [15] to satisfy the needs of Setiu region.

Hence, by including business variable in macro-management rules produce by [15], we could conclude that the basic loop introduce by [3], could be used in terms of producing Dynamic Model for this research.

The causal loop in the SD-AQEP model (Figure 4) that was introduced by [10], was used, it embodies the flow of material and energy in the Setiu Wetland environmental chain [10] [13]. The blue arrows track the positive effects of output (e.g. environmental processes and wastewater) and the red arrows the negative effects (e.g. land acquisition and disruption of natural habitats). The yellow arrows trace the formulation and implementation of policies.

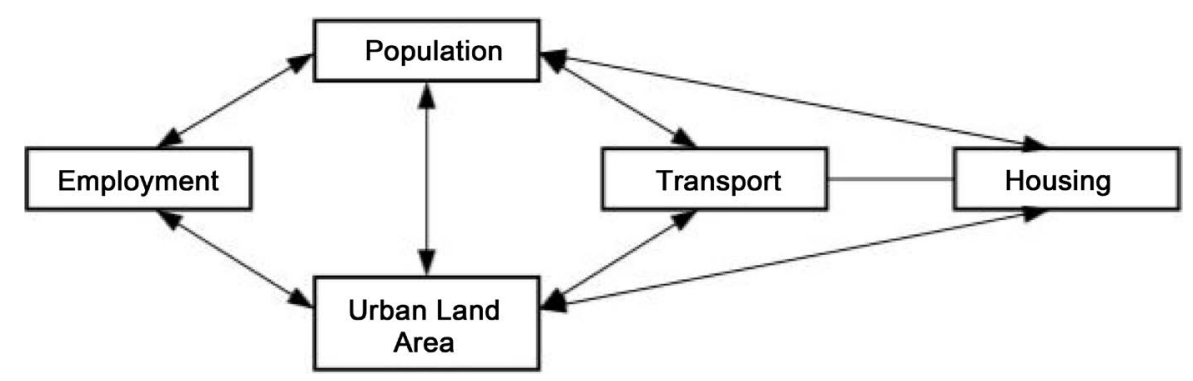

Figure 2. Causal-effective diagram at micro level by [15].

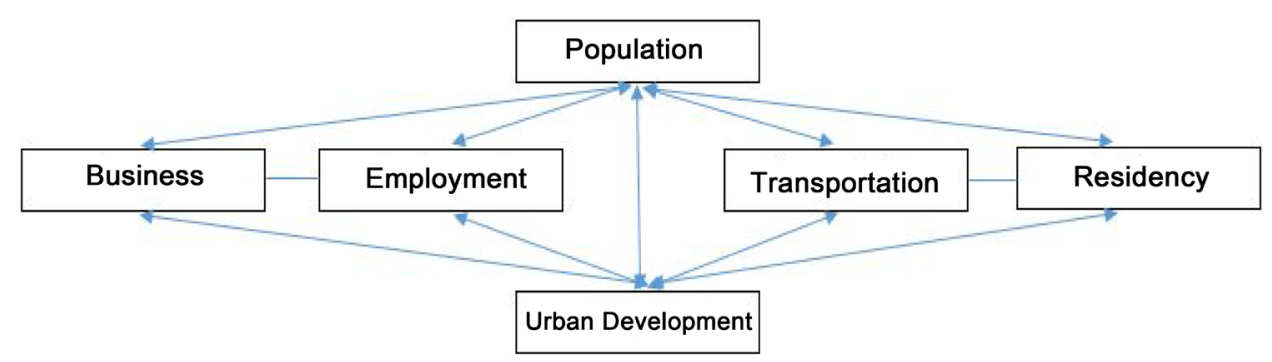

Figure 3. Reconstruction of cause-effect diagram by including business variable. 


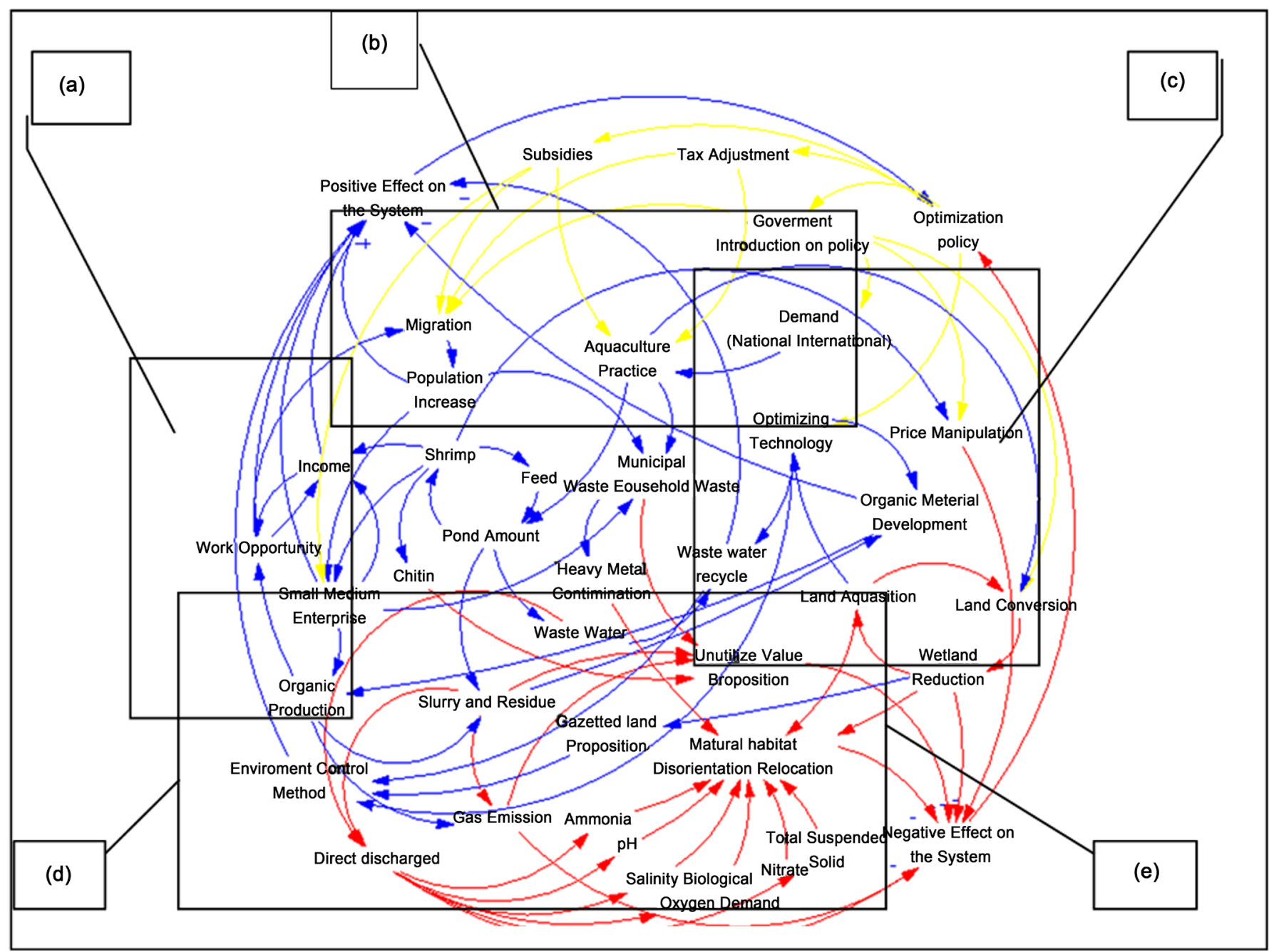

Figure 4. The Setiu Minapolitan-Dynamic System are derived from the partial casual loop of SD-AQEP and its Stock-Flow Model by [3] (For figure a., b., c., d. \& e. please refer Appendix A).

\section{Data Sources}

Economic and livelihood model used in system dynamic represent a certain sector involved directly in Setiu stakeholder. The relation between livelihood and economic exists symbiotically as each end effect another. Therefore, several components that should be listed and account for.

\subsection{Population, Urban and Accommodation}

Population sectors play a significant role in terms of affecting other sectors. For any change in this sector, refer to the quantity and structure of the population, which will directly change the other five sectors. Relatively, the total officially registered population in Setiu Pseudo-Minapolitan until 2015 are listed in Table 1.

With average population growth relatively $0.798 \%$ over ten years, starting from 2000 to 2010 [27] [28] the growth rate in Setiu Wetland are relatively low compared to other district in Terengganu. Major contribution for population growth is from birth rate, 
Table 1. Total registered population and land cover in setiu pseudo-minapolitan (setiu wetland) until 2015.

\begin{tabular}{cccc}
\hline \multirow{2}{*}{ Area } & \multicolumn{3}{c}{ Population of Setiu Minapolitan } \\
\cline { 2 - 4 } & Land Size (Hectare) & Population & Population Density $\left(\mathrm{ppl} / \mathrm{km}^{2}\right)$ \\
\hline Hulu Nerus & $54,523.3$ & 12,592 & 23.09 \\
Chalok & $20,589.6$ & 14,854 & 72.14 \\
Hulu Setiu & $23,292.9$ & 3198 & 13.73 \\
Guntung & $16,348.5$ & 7424 & 45.41 \\
Tasik & 5827.1 & 7227 & 124.02 \\
Pantai & 8499.4 & 5994 & 70.52 \\
Merang & 6825 & 3198 & 46.86 \\
\hline
\end{tabular}

a. Sources: [27] [1].

$65 \%$, and migration rate, $25 \%$ [27]. The average density in Setiu Region is $42.6 \mathrm{inh} / \mathrm{km}^{2}$ [28], which is the second lowest in Terengganu State.

Despite being the second lowest density in Terengganu state, vast land was allocated for housing in Setiu Wetland [29] [30]. Hence, this creates a pandemic regarding low land use, effectiveness rate where some of the allocated land was left with minimal care or abandon. However, utilizing this vacant land is not possible due to its ownership rights. There are some cases of awarded land being sold to outsiders by the locals despite the land bestow to them were purposely should be used to increase their household income in the long run [29].

\subsection{Economic and Employability}

The number of businesses, employment rate, household income earning from various minapolitan activities are included onto factors that affecting the economic sector in Setiu Wetland. Roughly around 70\% business in the Setiu Wetland area are Sole Proprietorship [31], while others are Partnership or Holdings.

Despite the massive number of registered businesses, the total employment and work opportunity are quite low in Setiu Region especially in Setiu Wetland [29]. Lacking of working opportunity and relatively low income in the Setiu Wetland region contribute towards a significant number of emigrants of younger generation seeking a better opportunity [29]. However, small business related towards marine and fisheries were thriving despite of low general populations [1] [29] [30].

Majority residence in this particular area works as a small fisherman and their relative income, average MYR700 for catchment seasons (March to October). For rainy seasons, their relay onto government subsidies or MYR200 per month due to monsoon seasons [29]. A part of that, some residences in this particular area involve small and the self-sufficient agricultural sector as in Figure 5. Relatively around $10 \%-15 \%$ of this 
farmer earn an average to MYR850 per month from their agriculture industries [29].

\subsection{Development and Amenities}

Amenities in Setiu District include of government buildings, banks, and utilities center located in the heart of Setiu (Bandar Pemaisuri), for educations and welfare, in a total of forty-six (46) primary and secondary school, one (1) public university, one (1) general hospital, one (1) District Branch Library located in Bandar Pemaisuri, Setiu, and eleven (11) rural library located in various residency area. Although it seems sufficient theoretically to cover the total population density in Setiu District, however, in some rural area such as Setiu Wetland, had some difficulty in order to access this public amenity due to the total distance travelled to reach such services. The crucial services that are in needs are such as; bill payment, post offices, government service center (for identification card, passports and etc.), and some shops that are insufficient in Setiu Wetland.

\section{Model Simulation and Limitation}

The System Dynamic model is simulated under two different environments, High Minapolitan Urban-Development Policy, (HiMDP) and Low Minapolitan Urban-Development Policy, (LiMDP) as shown in Table 2. Throughout analysis and discussion of

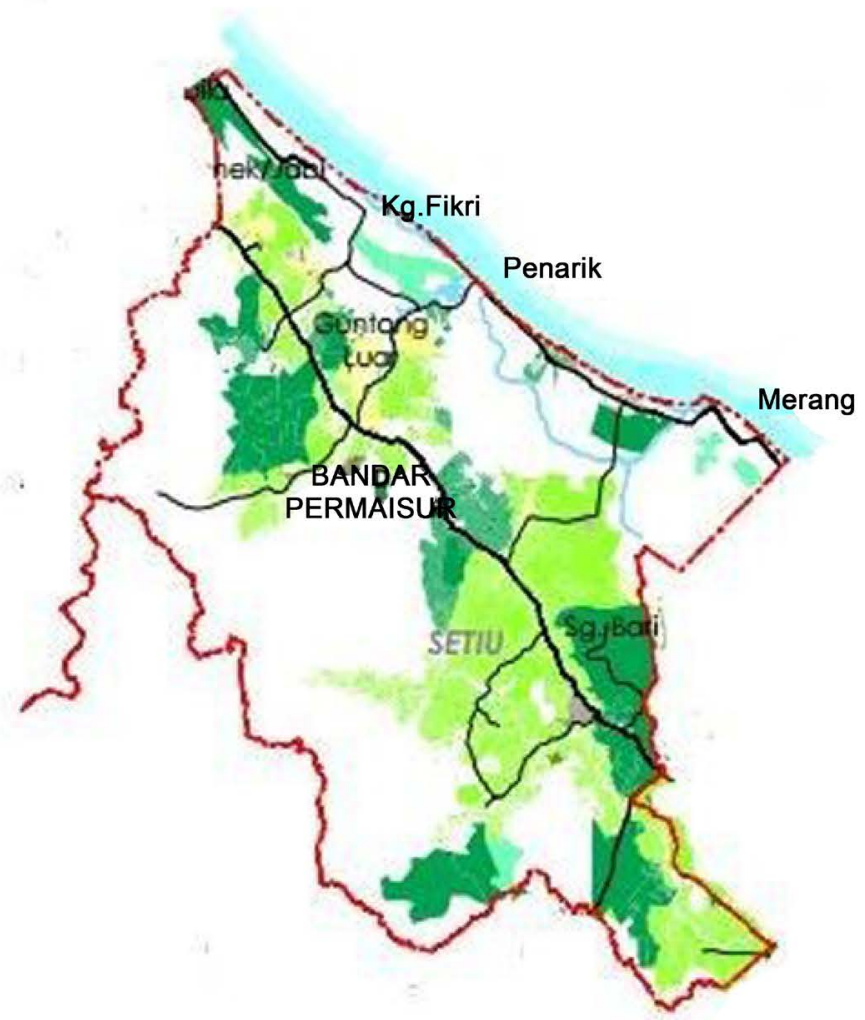

INDICATOR

$\square$ Rubber Tapper Palm Oil

Paddy

Coconut

Orchard

Short-term Crop
Main Road

Road

River

KITARA Border District Border State Border

Figure 5. Setiu Agriculture Distribution Maps [32]. 
Table 2. Total Registered Population and Land Cover in Setiu Pseudo-Minapolitan (Setiu Wetland) until 2015.

\begin{tabular}{ccc}
\hline & \multicolumn{2}{c}{ Coefficient of Population Density for application } \\
\cline { 2 - 3 } Population Density (Person per $\mathrm{km}^{2}$ ) & HiMDP & LiMDP \\
\hline $0-50$ & 1 & 0.9 \\
$51-100$ & 0.5 & 0.4 \\
$101-500$ & 0.2 & 0.1 \\
$>500$ & 0 & 0 \\
\hline
\end{tabular}

a. Sources: [27] [33]-[36].

each analysis using HMUD and LMUD (hereinafter will be used into the analysis description), its advantages and disadvantages, different and similarity, and also distinctive policy approaches will be included in the result.

However, the development of this simulation model is limited in terms of new prospects of development that were comparable to new developed sub-urban sprawl. This is due to the limitation of development schemes, and lack of adequate research related towards this particular subject. Hence, the development model is limited in terms of utilizing existing development scheme provided by the local government, and hence in hope that the model could provide insights for future and the recommendation could be a kick-starter for something bigger.

\subsection{Population, Business and Employment Simulation}

The difference between two simulated results brought by the differences of population growth (Figure 6(a) \& Figure 6(b)), under HiMDP, the enterprises enjoy a higher, increasing pace due to the blooming of the population. Basic economic rules applied when the demand of items such as household items and etc. from local increases due to the increment of population (Figure $7(\mathrm{a})$ ). Hence, some migration will definitely occur due to the increase of socioeconomic benefits and produce more desired effect in terms of producing a minapolitan district. However, under LiMDP, the population growth is significantly slower until it hit stagnant. This probably due to the economic capacity of certain places reach its limits, hence, produce low business bloom and lower the socioeconomic income. In the worst case scenario, migration of locals will occur in order for them to satisfy the needs of household economic needs (Figure 7(b)).

\subsection{Development, Housing Demand and Amenities}

The demand of rail transport, new roadways and efficient public transportation increase in HiMDP. The advantages for the development of particular amenities are; giant transmits capacity, low congestion, high degree of comforts, high degree of environmental friendliness and promote import and exports of local produce (fish and marine produce). While under LiMDP, the development of public transportation and demand of the railways are almost none, hence it will produce low levels of locomotion 


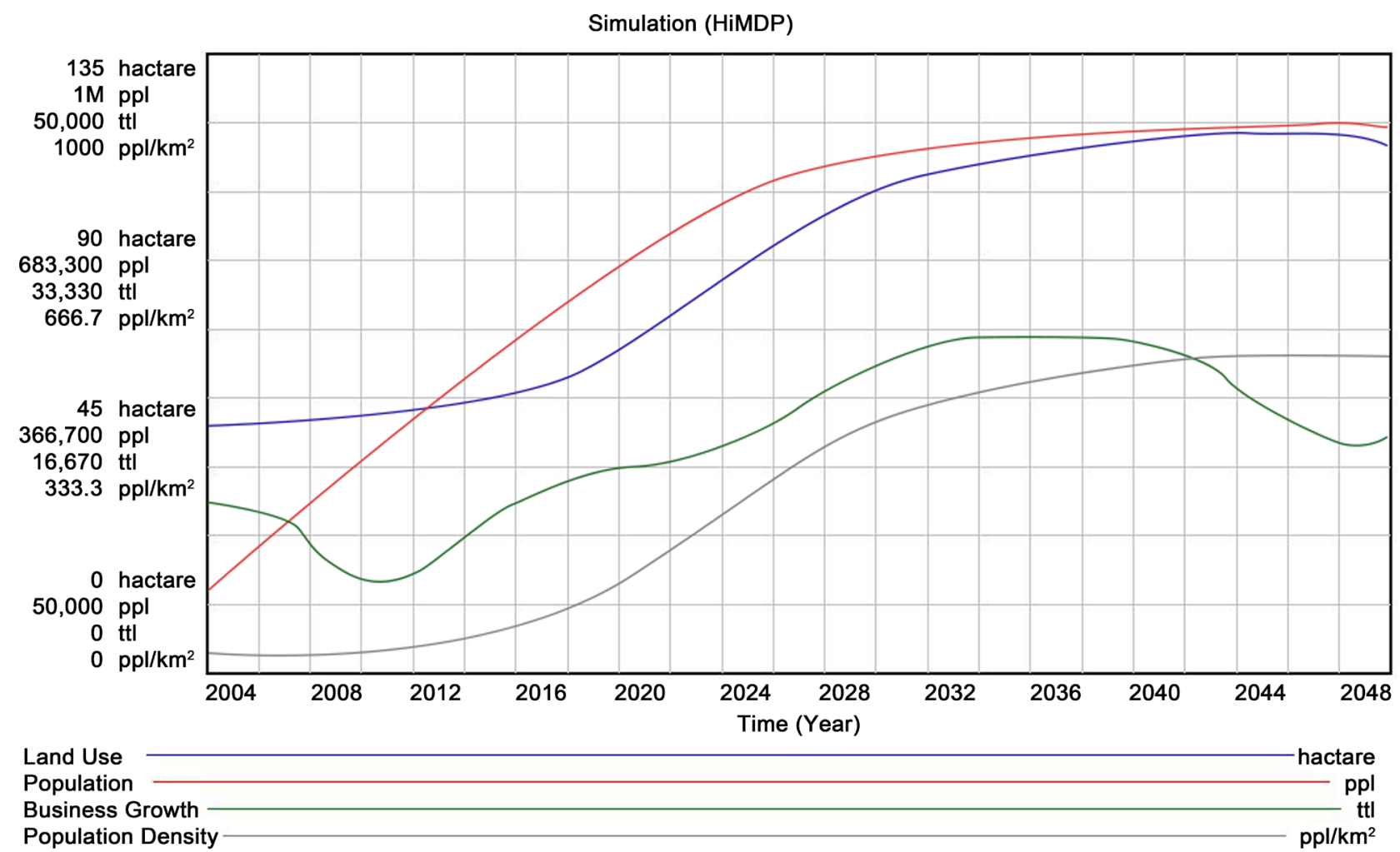

(a)

Simulation (LiMDP)

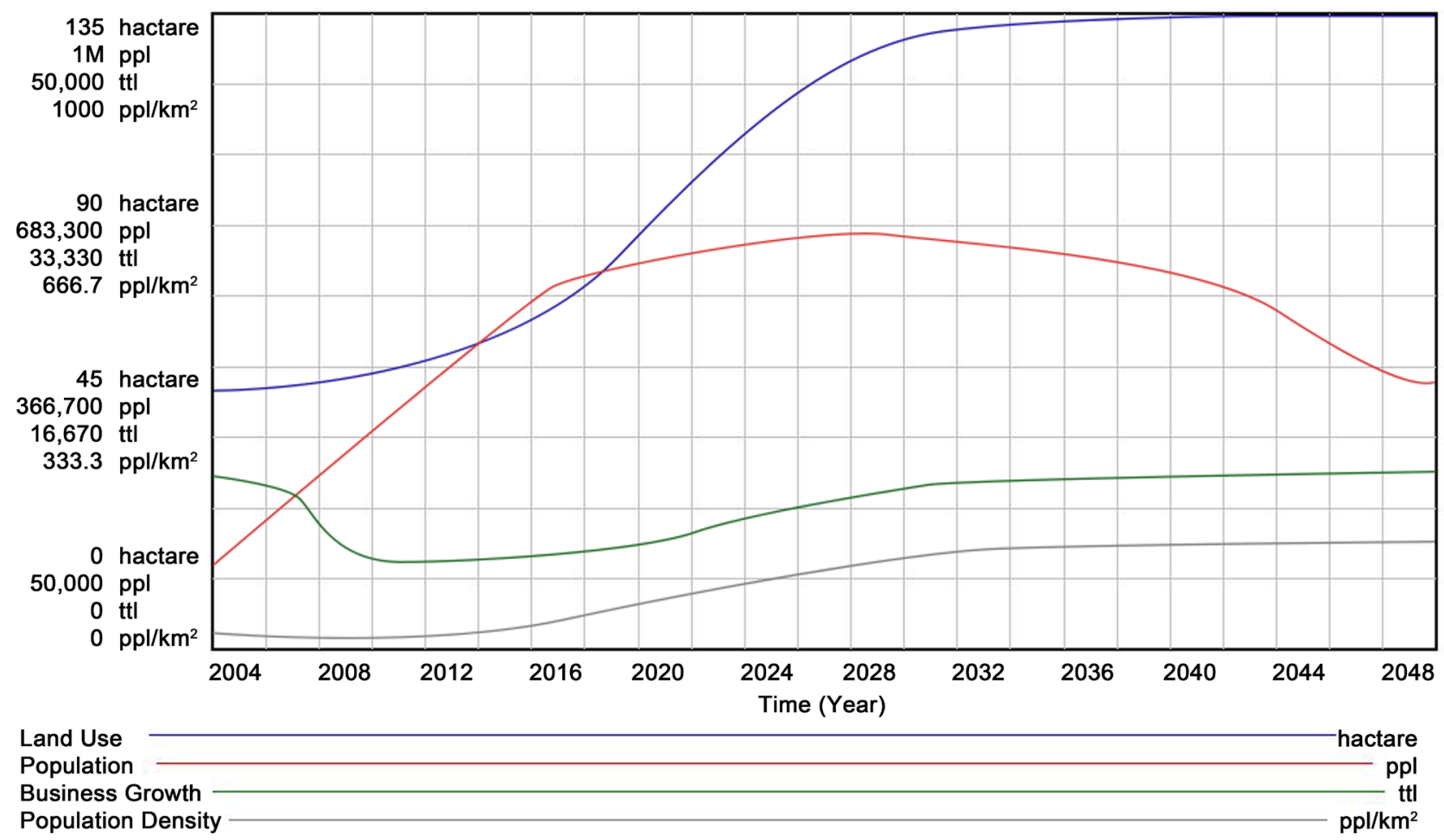

(b)

Figure 6. Simulation Result 1 under HiMDP and LiMDP scheme. 


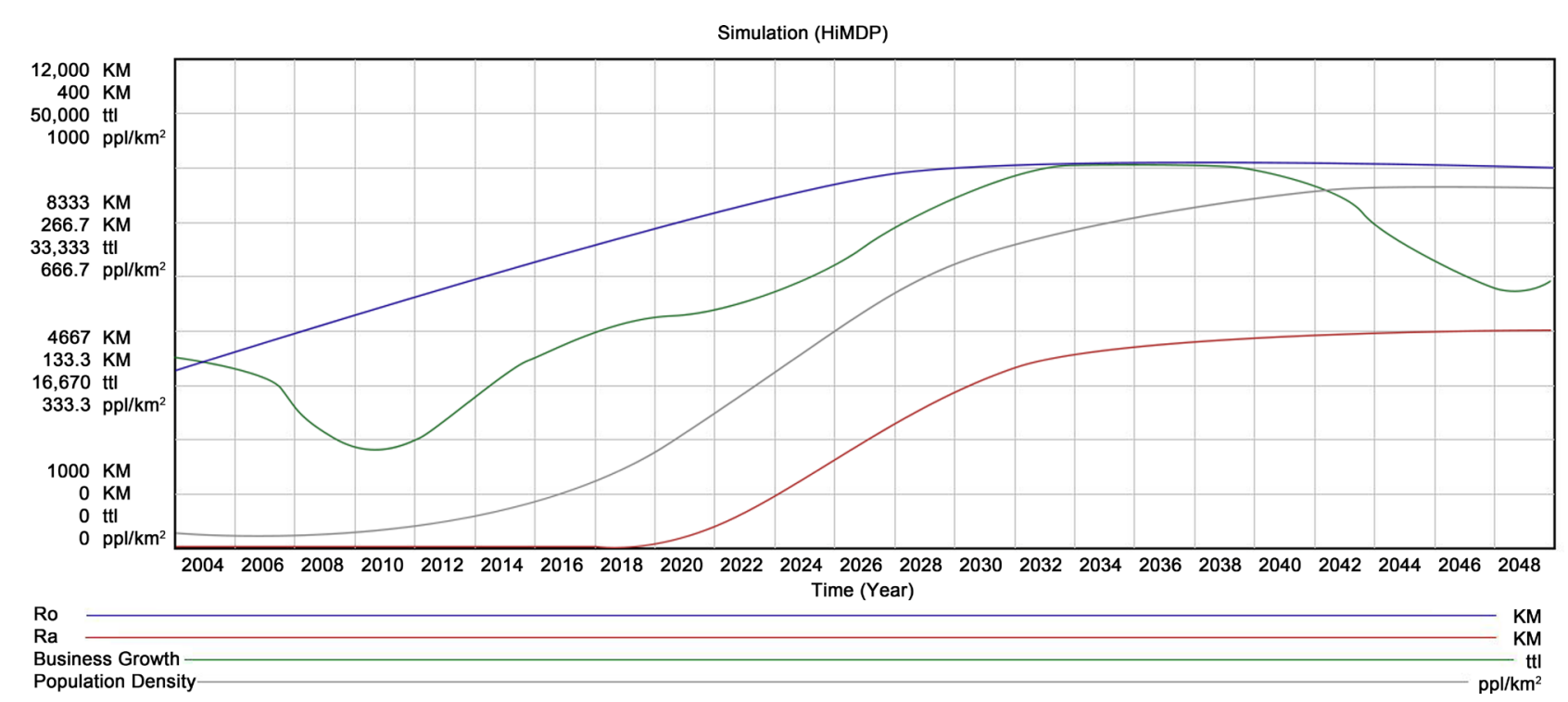

(a)

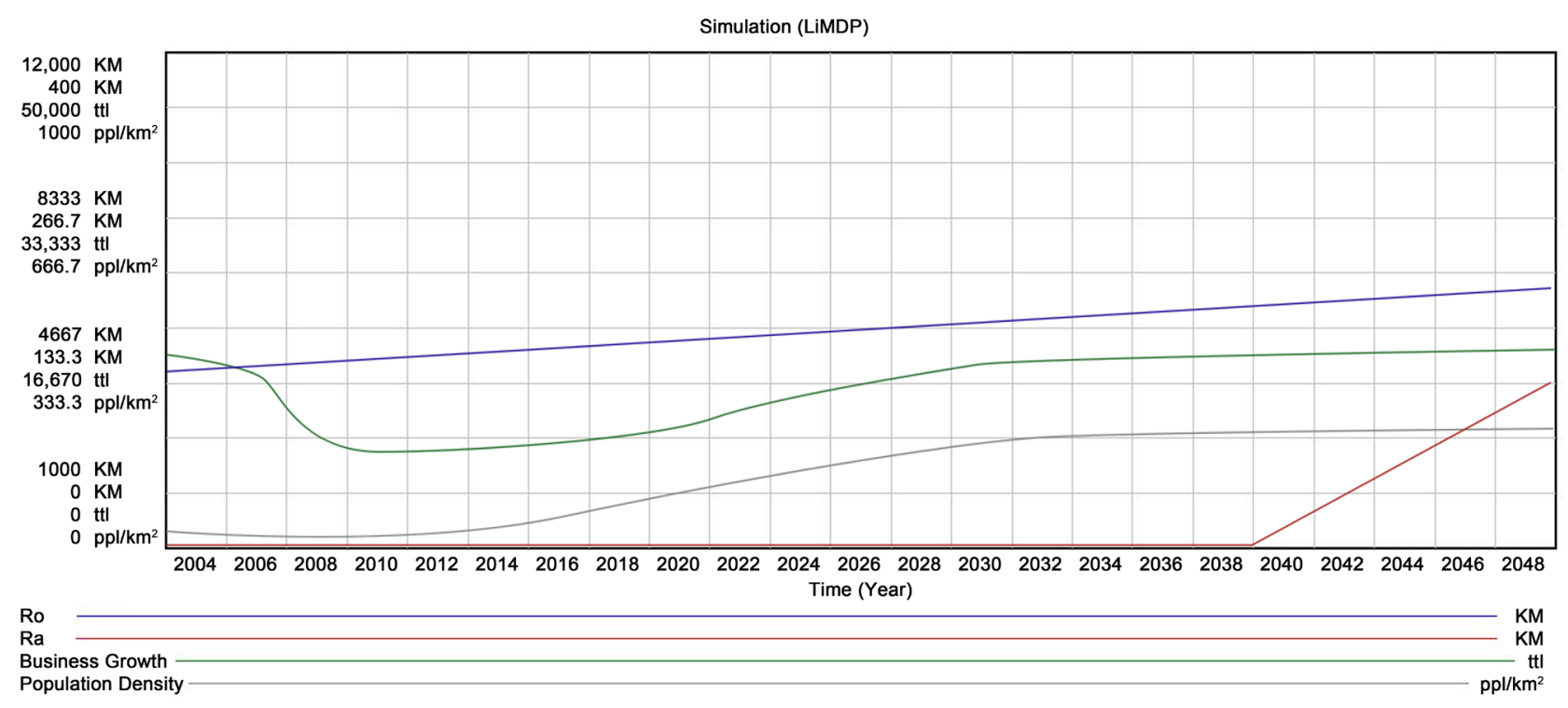

(b)

Figure 7. Simulation Result 2 under HiMDP and LiMDP scheme.

and reduce import and export of local produce.

\subsection{Transportation}

A simulation model of transportation conducted under two different schemes produce significant results (Figure 8(a) \& Figure 8(b)). Transportation routes bloom rapidly under HiMDP scheme, where roads and railway development are rapidly increasing due to the increase of demand and population. Hence, the traffic congestion could be avoided and charter transportation of goods and commodity could be achieved. This promotes more blooming of business and more energy efficiency. Not to mention, produce more comfortable journey for the local population. However, under LiMDP 


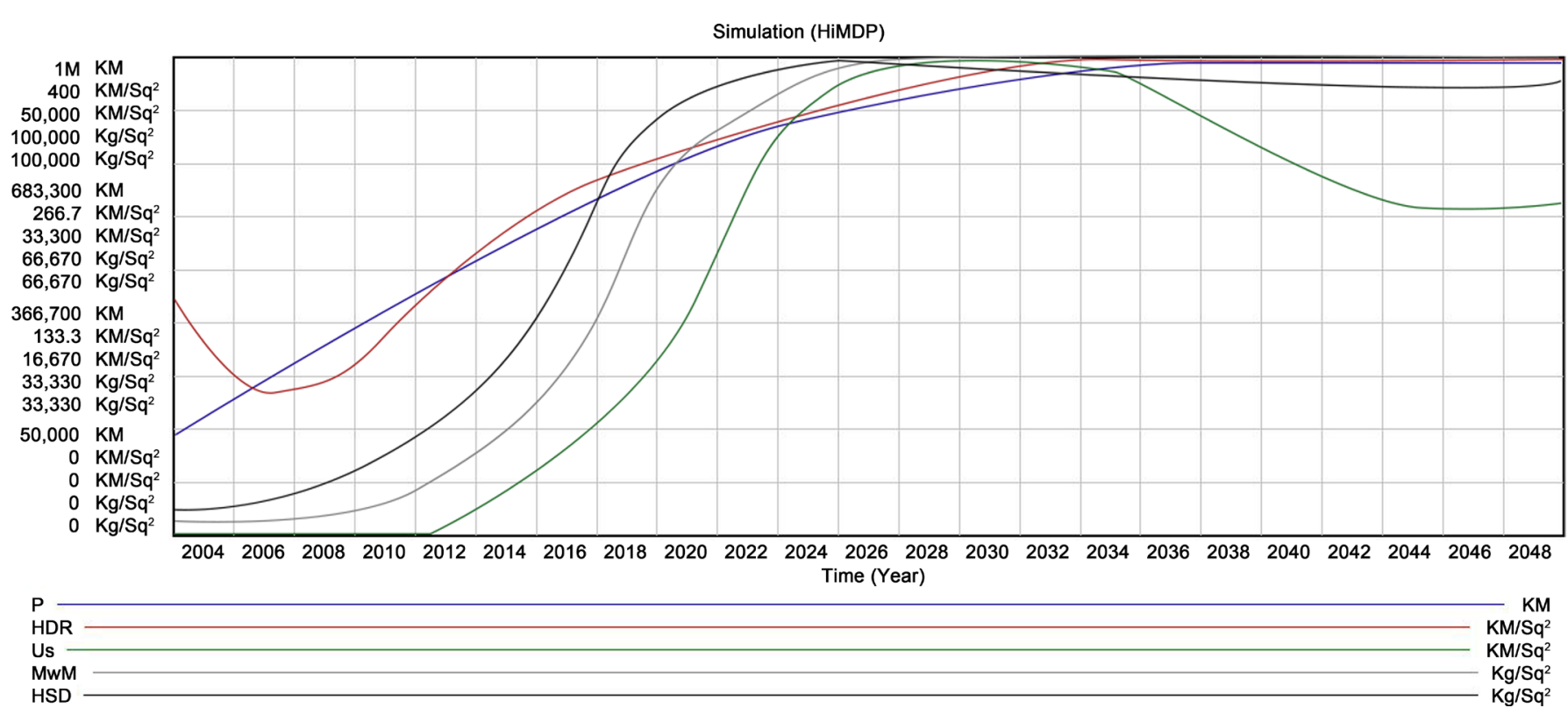

(a)

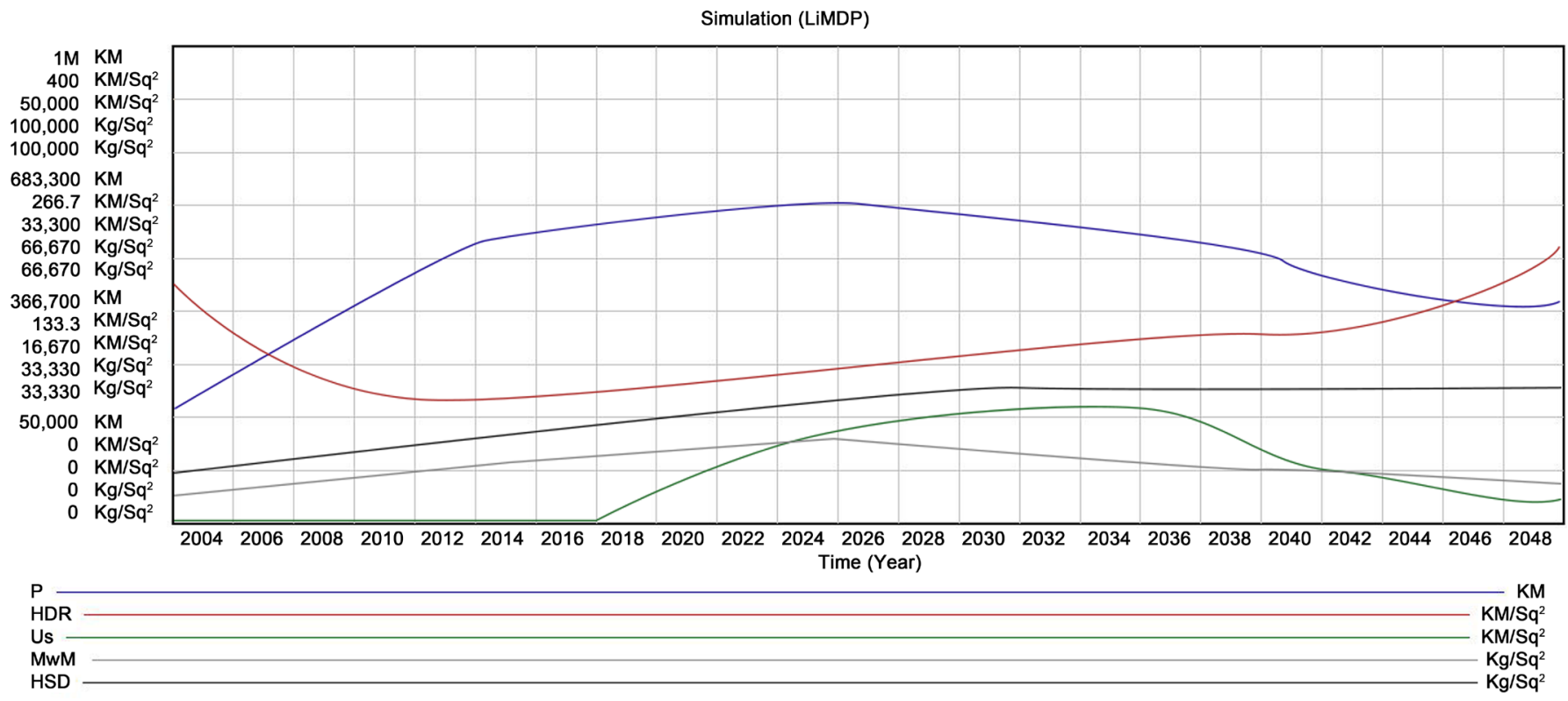

(b)

Figure 8. Simulation Result 3 under HiMDP and LiMDP scheme.

scheme, the transportation route isn't developed rapidly as compared to HiMDP. This is due to the low development rate and lower demand for energy efficient and speed related transportation. The lower development rate however will not produce traffic congestion as the lower amount of population and low usage of public transportation means.

\section{Policy Suggestion}

Ignoring the interactive relationship among variable, generally leads to the establishment of other new problems that require solving [37]. Therefore, all the development 
and policies that were introduced, environmental sustainability aspect should be taken into consideration [38] [39]. Hence, by using the result generated by System Dynamic model with HiMDP and LiMDP scenario, we produce any policy recommendation for future development of Setiu Minapolitan.

\subsection{Housing and Urban Planning}

Land uses for public housing sectors can be maximized and the usage of land should be optimized to be more profitable and produce a more promising housing area that can uphold expansion of population [39]. By implementing housing, zoning to promote urban spawning, a more sophisticated neighborhood with basic necessity ought realized hence promoting population growth and incoming migrate [38]. Next, throughout the analysis, government should not be awarding more land to preserve the basic land reserved for future project. Policies of leasing-holding for newcomers should be implied with several land conditions to promote high speed development based on the needs of local and state government agenda. This scheme should be able to demonstrate enough evidence to the stakeholder and promote migration of residence to bloom the local economy.

\subsection{Development and Amenities}

Local authorities should be focusing on to providing basic needs of amenities for fully functioning community. Things like post stations, local central clinics and one-stop center is crucial for development of rural area to a peri-urban area. This is because, locals from Setiu Wetland areas such as Kg. Rhu 10, Kg. Telaga Papan, Kg. Mangkuk, Taman Hijrah, and several more places had to travel to the nearest post station in Kuala Nerus border or straight to Jertih to experience some of the basic amenities that are insufficient in the Setiu Wetland area. Other facilities that should develop in Setiu Wetland are UTC center that includes all participating government services into one roof. This could be beneficial in terms of promoting growth in the Setiu Wetland area.

\subsection{Locomotion and Transportation}

Public transportation is finite in Setiu Wetland compared to the urban area of Setiu (Pemaisuri and etc.). Hence, the locals are restricted from accessing certain location using public transportation.

Locomotion for goods and certain commodities are limited due to lengthy distribution pattern from its sources towards Setiu rural area. Hence, the goods are a bit pricey and some commodity limited. Therefore, in order to solve the access problem as stated, the suggestion is by developing new transportation such as railway. Hence this could reduce time of transportation and reduce the costing for commodities in the Setiu Wetland area and promote export of local goods.

\subsection{Business and Employments}

Theoretically, by promoting business growth, the total employed population density 
will plummet. Hence, to develop and promoting employment in Setiu Wetland, the business must first bloom here. There are several factors should be taken into consideration such as population and locomotion of goods [40] [41] [42]. Hence, by strengthening both population and locomotion aspects, we believed, the business will bloom and employed population density will rise. However, there are some recommendation that can be taken into consideration for state authorities, such as; enhancing business network to create business environment and inviting big players to Setiu. Next, allocating a suitable business area to grow without neglecting the sustainability of the environment and conservation area's needs. Focusing onto tourism industry and promoting Setiu as a gateway for robust tourism and leisure lifestyle [42]. Last but not least, invest in community development based on their specialty. This cloud be promoted as a tourism attraction of locals that can be promoted internationally. By taking into consideration of the business environment enhancement idea, surely, Setiu could be one of the most places that produce highest employed population density in Terengganu.

\section{Conclusions}

Environmental development is highly complex, and involves a system of interwoven components with numerous positive and negative feedback loops [40] [43] [44], so it is a sustainable development of Setiu Minapolitan. In this study, the dynamic and changes in Setiu Wetland Minapolitan are simulated and analyzed. The dynamic model that integrates all important factors in town planning and development that could be used to assist the evaluation of possible Government policy impact towards sustainable land use in Setiu Wetland. To avoid mistake in terms of simulation, some precaution was taken using sensitivity check throughout the model. The model examines the interaction between six-sub sectors within a 30 years' time frame. Consequently, some model undergoes 100 years simulation to produce a more reliable simulation in order to assists the sensitivity check.

Based on the simulation, observation, some improvement could be applied in the simulated environment to help this particular area to thrive in both economical and livelihood. However, this study also could be used to generate other simulations to assist policy makers to understand the challenges and effects of each road taken in terms of developing Setiu. Hence, several recommendations could be taken into consideration: 1) System dynamic could be used to simulate supply and demand of local marine products to widen Setiu Minapolitan horizon further; 2) Stimulate economic development cost production and its limiter; 3) Stimulate interaction of local development model and its effects on the environment for a sustainable livelihood; 4) Simulate spatial limiter towards cultural and heritage upon upcoming development; 5) Simulate local tourism industry; as a catalyst of economic development and its impact; 6) Simulate major player in the aquaculture industries for its economical spillover or impact towards local residence.

In a nutshell, the result of answering the "What if" questions using a dynamic model and simulation should be beneficial in the long term for parties involved in decision making. 


\section{Acknowledgements}

This study supported by Niche Research Grant Scheme (NRGS) for Setiu Wetland Development P1 (R) (Second Phase) Vote No.: 53131/30, Ministry of Higher Education Malaysia. Acknowledgement for Terengganu Economic Development Unit (UPEN), YDSM, Setiu District Welfare and Safety Committee (JKKK) and Setiu Overall Population for providing insights during interview and questionnaire sessions.

\section{References}

[1] UPEN (2015) Penerangan Pelan Strategik Setiu. (Naeim, M. and Mohd, N.A.R., Interviewers)

[2] Nakisah, M.A. and H.F.A. (2003) Setiu Wetlands: Tranquility Admist Plenty. Talisman Energy Inc., Terengganu.

[3] Safiih, M.L., Mohd, N.A., Naeim, A.R., Ikhwanuddin, A.M., Madzli, H., Syerrina, Z. and Marzuki, I. (2015) A System Dynamics Model for Analyzing the Eco-Aquaculture System with Policy Recommendations: Case Study on Integrated Aquaculture Park ( $i$-Sharp), Setiu, Terengganu, Malaysia. AIP Conference Proceedings, 1750, Article ID: 060003.

[4] CCICU (2015) [Setiu Breakdown Maps, Setiu, Terengganu, Malaysia]. https://ukka.unisza.edu.my/international/index.php?option=com content\&view=article\&id $=72 \&$ Itemid $=280$

[5] Google Maps (2015) [Setiu, Terengganu, Malaysia] [Street Map] [Earth Map]. https://www.google.com.my/maps/search/sungai+chalok/@5.5762826,102.7973627,8379m/ data $=! 3 \mathrm{~m} 1 ! 1 \mathrm{e} 3$ ?hl=en

[6] WWF (2003) Project: Sustainable Management of Setiu Wetlands: A Setiu Wetland Wonder. WWF-Malaysia.

[7] Mu'tamar, F.M., Eriyatno, M. and Soewardi, K. (2013) Dynamic Model Analysis of Raw Material Supply in Minapolitan Shrimp Agroindustry. Industrial Engineering Letters, 3, 3644.

[8] Rukmono, M. and Dewi, S.T. (2010) Potensi Pengembangan Kawasan Minapolitan di Kecamatan Berbah, Kabupaten Sleman. Jurnal Perencanaan Wilayah dan Kota, V4N1, 179188.

[9] YDSM (2015) Kegiatan Ekonomi, Perancangan Pembangunan, dan Pemuliharaan Setiu. (Mohd, N.A.R., Interviews)

[10] Safiih, M.L. and Mohd, N.A.R. (2015) System Dynamics Approach in Setiu Minapolitan: An Economical and Livelihood Review. International Conference of Mathematical and Statistic (ICMS), Paris, 25-26 June 2015, 20-29.

[11] Nobre, A., Musango, J., Wit, M.D. and Ferreira, J. (2009) A Dynamic Ecological-Economic Modeling Approach for Aquaculture Management. Ecological Economics, 68, 3007-3017. http://dx.doi.org/10.1016/j.ecolecon.2009.06.019

[12] Owen, S. and Cowell, R. (1994) Lost Land and Limits to Growth: Conceptual Problems for Sustainable Land Use Change. Land Use Policy, 11, 168-180. http://dx.doi.org/10.1016/0264-8377(94)90020-5

[13] Forrester, J. (1958) Industrial Dynamics: A Major Breakthrough for Decision Makers. Harvard Business Review, 36, 37-66.

[14] Mebratu, D. (1998) Sustainability and Sustainable Development: Historical and Conceptual Review. Environmental Impact Assessment Review, 18, 493-520. 
http://dx.doi.org/10.1016/S0195-9255(98)00019-5

[15] Shen, Q., Chen, Q., Tang, B., Stanley, Y., Hu, Y. and Gordon, C. (2009) A System Dynamic Model for the Sustainable Land Use, Planning and Development. Habitat International, 33, 15-25. http://dx.doi.org/10.1016/j.habitatint.2008.02.004

[16] Deaton, M.L. and Winebrake, J.J. (2000) Dynamic Modelling of Environmental Systems. Springer, New York. http://dx.doi.org/10.1007/978-1-4612-1300-0

[17] WWF (2009) WWF Annual Review 2009. WWF-Malaysia. http://www.wwf.org.my/?9880/WWF-Annual-Review-2009

[18] Roberts, E.B. (Ed.) (1978) Managerial Applications of System Dynamics: An Introduction, Pegasus Communications, Waltham, 3-35.

[19] Chang, Y., Hong, F. and Lee, M. (2008) A System Dynamic Based DSS for Sustainable Coral Reef Management in Kenting Coastal Zone, Taiwan. Ecological Modelling, 211, 153-168. http://dx.doi.org/10.1016/j.ecolmodel.2007.09.001

[20] Sterman, J.D. (1992) System Dynamics Modeling For Project Managment. System Dynamics Group Sloan, School of Managment, Massachusetts Institute of Technology, Cambridge.

[21] Sterman, J.D. (2000) Business Dynamics: Systems Thinking and Modeling for a Complex World. Irwin McGraw-Hill, Boston.

[22] Wang, Y. and Zhang, X. (2001) A Dynamic Modeling Approach to Simulating Socio-Economic Effects on Landscape Changes. Ecological Modelling, 140, 141-162. http://dx.doi.org/10.1016/S0304-3800(01)00262-9

[23] Tao, Z. (2010) Scenarios of China's Oil Consumption Per Capita (OCPC) Using a Hybrid Factor Decomposition-System Dynamics (SD) Simulation. Energy, 35, 168-180. http://dx.doi.org/10.1016/j.energy.2009.09.007

[24] Coyle, R.G. (1977) Management System Dynamics. Weiley, New York.

[25] Coyle, R.G. (1996) System Dynamics Modelling: A Practical Approach. Chapman \& Hall, London.

[26] Saysel, A.K., Barlas, Y. and Yenigun, O. (2002) Environmental Sustainability in an Agricultural Development Project: A System Dynamic Approach. Environmental Management, 64, 247-260.

[27] Department, N.A. (2012) Auditor General Report. National Audit Department, Malaysia.

[28] City Population (2015) [Setiu, Terenggany, Malaysia] [Home/Asia/Malaysia/Administrative Division] [Interactive Map]. City Population Website. http://www.citypopulation.de/php/malaysia-admin.php?adm2id=1307

[29] JKK (2014) Kegiatan Ekonomi dan Purata Pendapatan Penduduk Kampung Chalok, Bari, Rhu 10, Saujana, dan Padang Saujana. (Naeim, M. and Mohd, N.A.R., Interviewers)

[30] JKK (2014) Kegiatan Ekonomi dan Purata Pendapatan Penduduk Kampung sekitar Hulu Setiu dan Kuala Besut. (Naeim, M. and Mohd, N.A.R., Interviewers)

[31] SSM (2014) Penerangan Pelan Strategik Setiu. (Naeim, M. and Mohd, N.A.R., Interviewers)

[32] Terengganu Government (2006) Rancangan Struktur Negeri Terengganu 2005 hingga 2020. Kerajaan Negeri, Terengganu.

[33] UPEN (2011) Laporan Data Asas Negeri Terengganu Tahun 2011. Pencetakan Perbadanan Islam Negeri, Terengganu.

[34] UPEN (2012) Laporan Data Asas Negeri Terengganu Tahun 2012. Pencetakan Perbadanan Islam Negeri, Terengganu.

[35] UPEN (2013) Laporan Data Asas Negeri Terengganu Tahun 2013. Pencetakan Perbadanan 
Islam Negeri, Terengganu.

[36] UPEN (2014) Laporan Data Asas Negeri Terengganu Tahun 2014. Pencetakan Perbadanan Islam Negeri, Terengganu.

[37] Chen, M.C., Ho, T.P. and Jan, C.G. (2006) A System Dynamics Model of Sustainable Urban Development: Assessing Air Purification Policies at Taipei City. Asian Pacific Planning Review, 4, 29-52.

[38] Stearns, F. and Montag, T. (1974) The Urban Ecosystem: A Holistic Approach. Dowden, Hutchinson \& Ross Inc., Stroudsburg.

[39] Wheeler, S. (1996) Sustainable Urban Development: A Literature Review and Analysis. University of California at Berkeley Press, Berkeley.

[40] Bach, N.L. and Saeed, K. (1992) Food Self-Sufficiency in Vietnam: A Search for a Viable Solution. System Dynamics Review, 8, 129-148. http://dx.doi.org/10.1002/sdr.4260080203

[41] Li, F.J., Dong, S.C. and Li, F. (2012) A System Dynamics Model for Analyzing the EcoAgriculture System with Policy Recommendations. Ecological Modeling, 227, 34-45. http://dx.doi.org/10.1016/j.ecolmodel.2011.12.005

[42] Jin, M., Luo, Y., Liao, Z., Ren, P. and Gao, H. (2012) Sustainable Development of Economic Circle in Tourist Destinations Based on System Dynamics. Applied Mathematics \& Information Sciences, 3, 1011-1018.

[43] Teegavarapu, R.S.V. and Tangirala, A.K. (2005) Modeling Water Quality Management Alternatives for a Nutrient Impaired Stream Using System Dynamics Simulation. Journal of Environmental Informatics, 5, 73-81. http://dx.doi.org/10.3808/jei.200500048

[44] Yulong, C. and Smith, B. (1994) Sustainablity in Agriculture: A Genaral Review. Agriculture, Ecosystem and Environment, 49, 299-307. http://dx.doi.org/10.1016/0167-8809(94)90059-0 


\section{Appendix A}

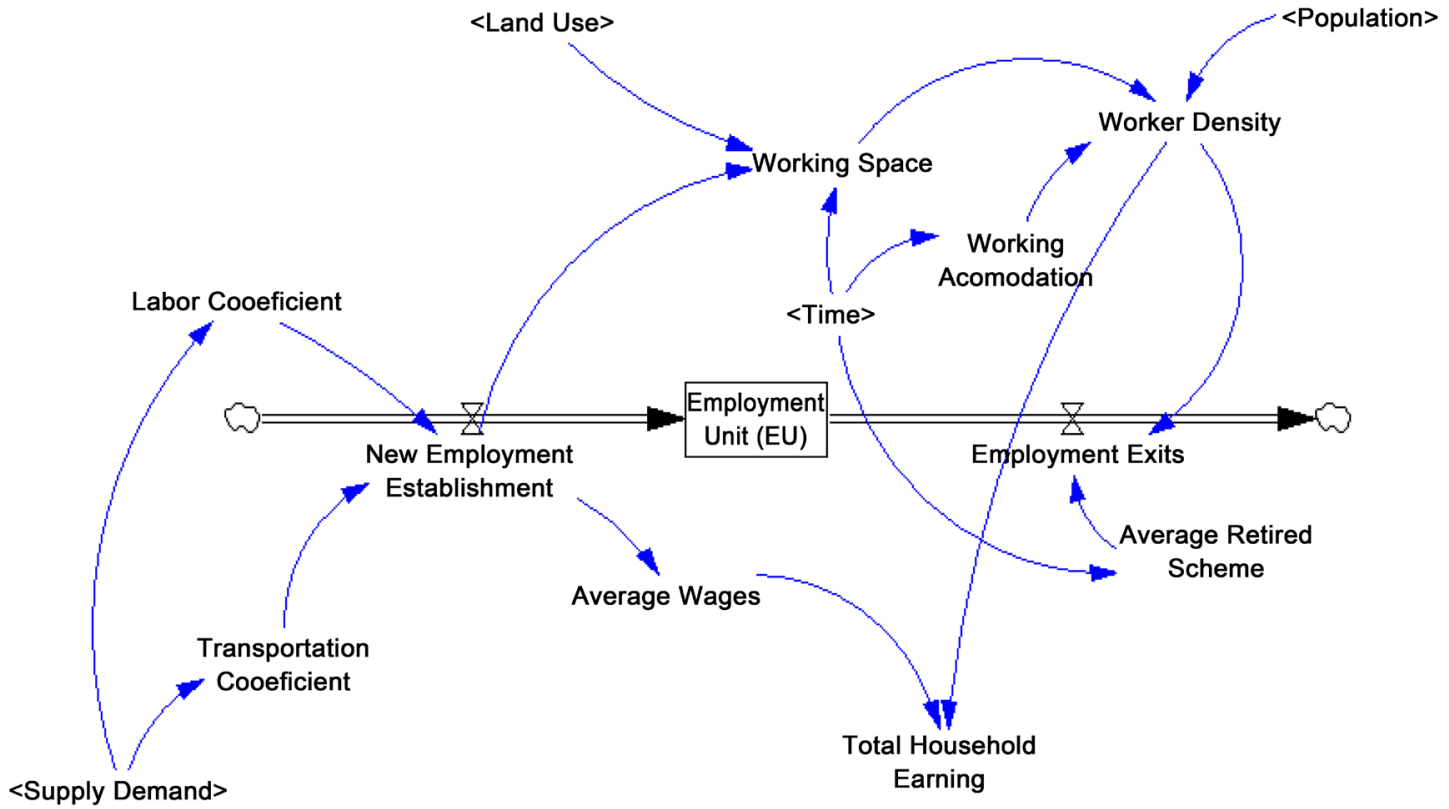

Figure 4(a). Employment dynamics from Figure 4.

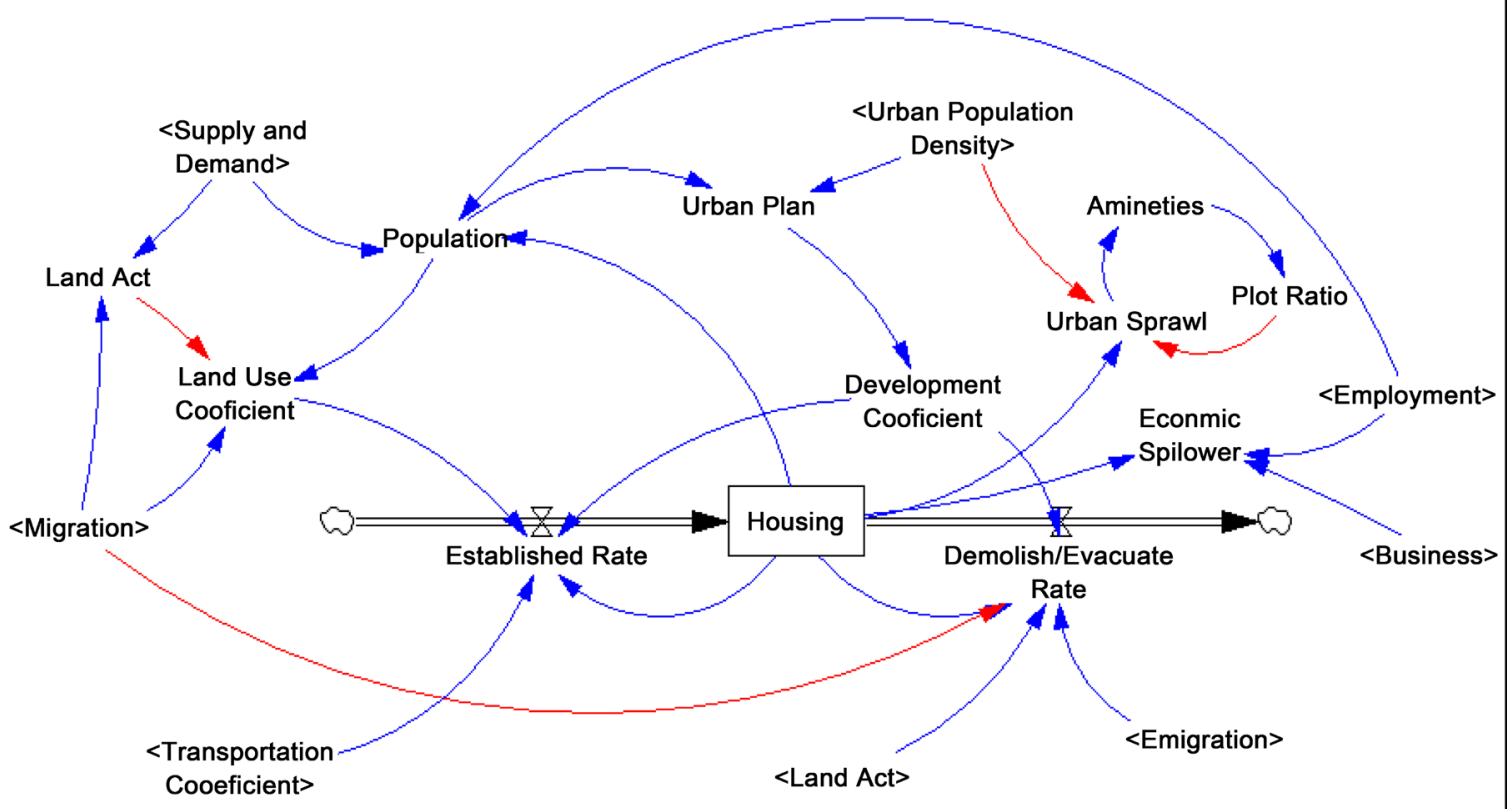

Figure 4(b). Land use and development dynamics from Figure 4. 


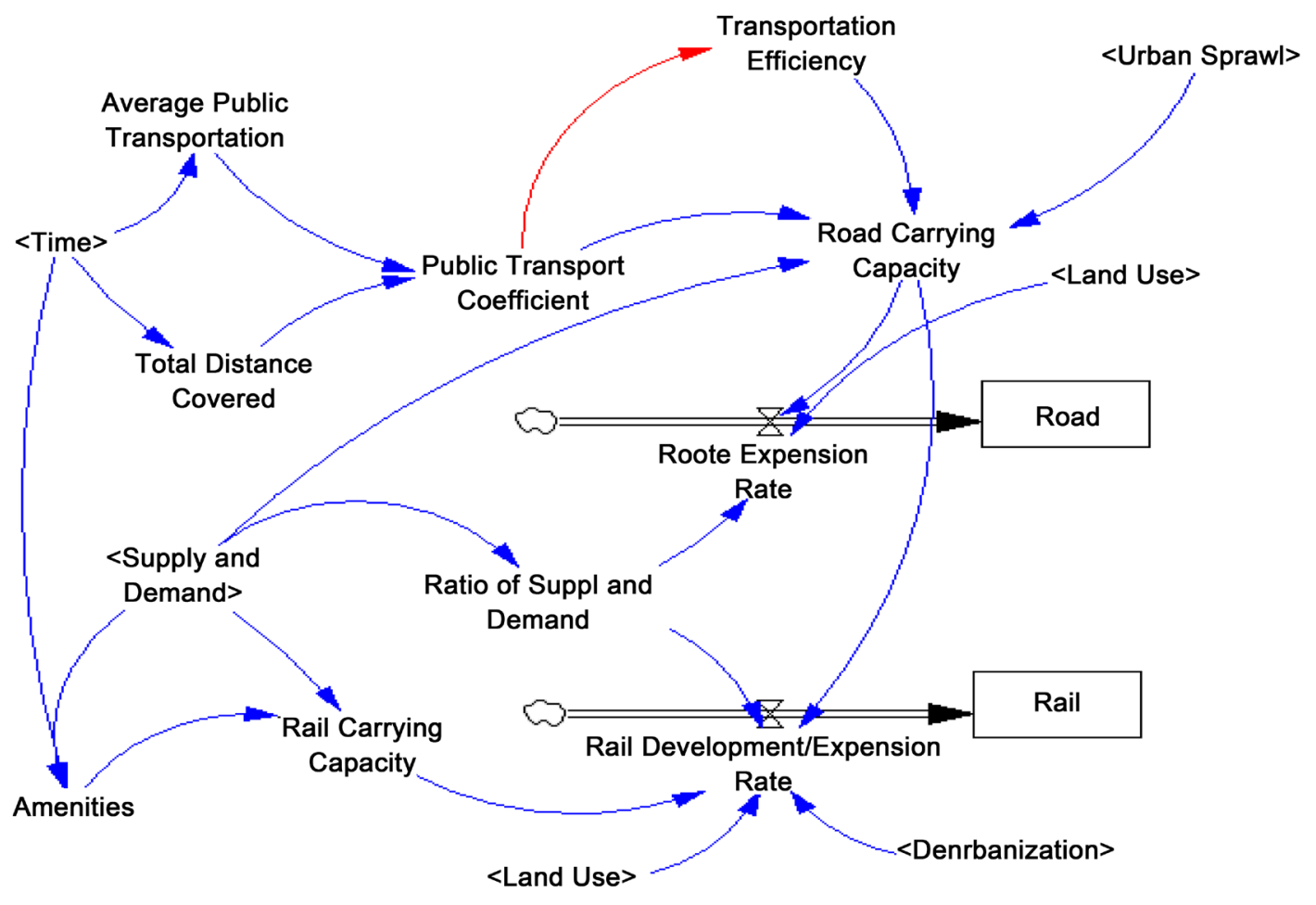

Figure 4(c). Transportation dynamics from Figure 4.

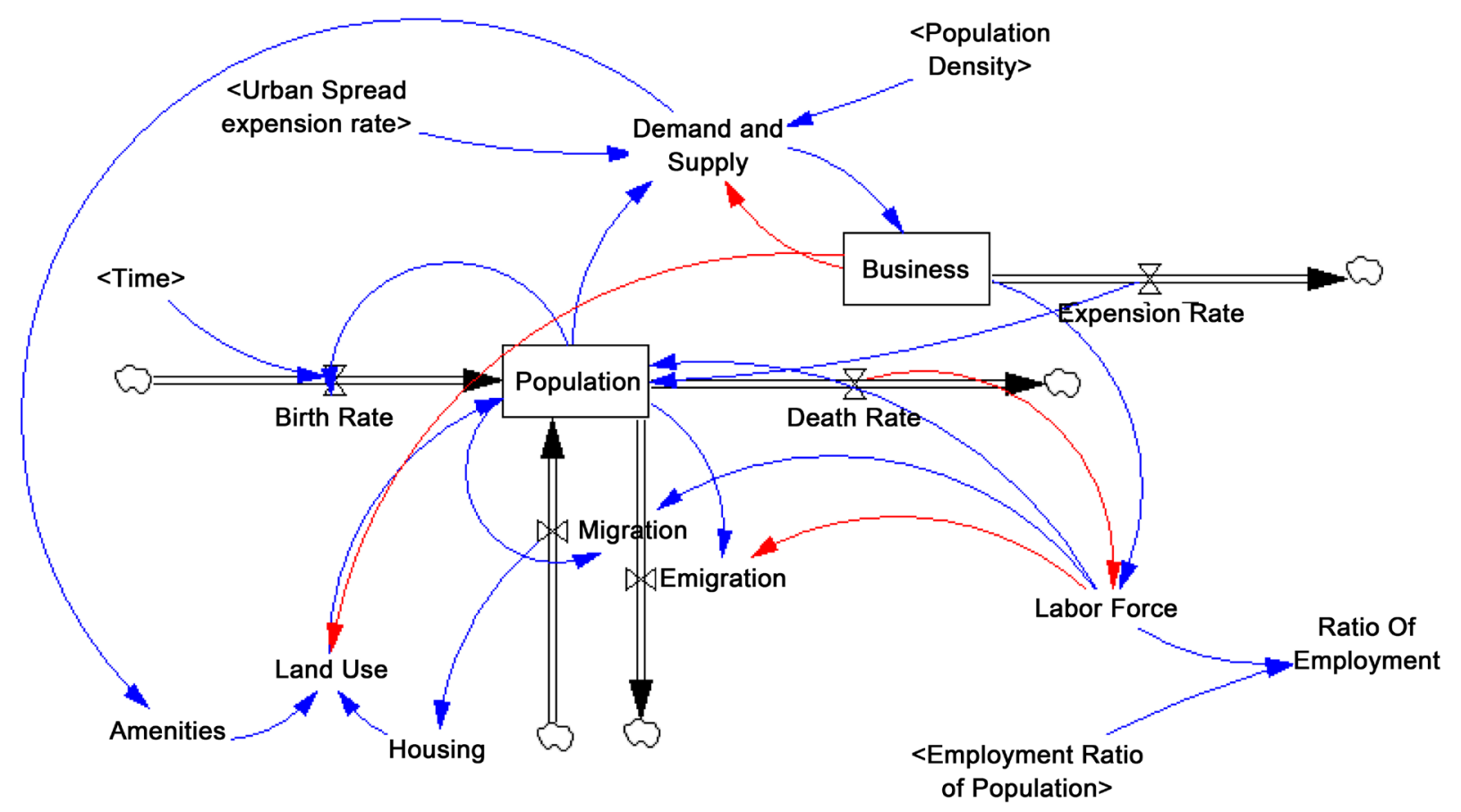

Figure 4(d). Population and business dynamics from Figure 4. 


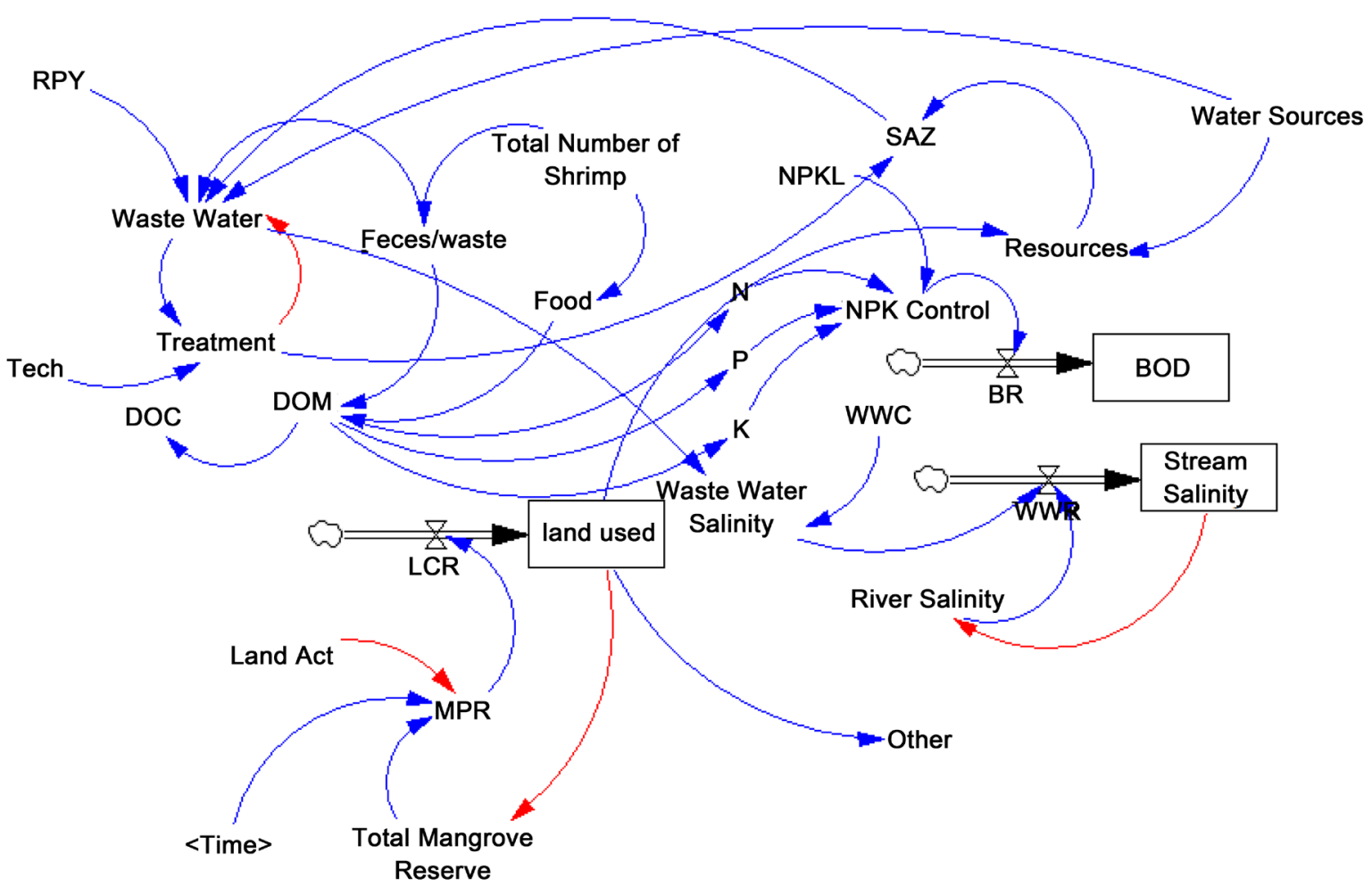

Figure 4(e). Waste water, MSW and Urban Dynamics from Figure 4.

Submit or recommend next manuscript to SCIRP and we will provide best service for you:

Accepting pre-submission inquiries through Email, Facebook, LinkedIn, Twitter, etc.

A wide selection of journals (inclusive of 9 subjects, more than 200 journals)

Providing 24-hour high-quality service

User-friendly online submission system

Fair and swift peer-review system

Efficient typesetting and proofreading procedure

Display of the result of downloads and visits, as well as the number of cited articles

Maximum dissemination of your research work

Submit your manuscript at: http://papersubmission.scirp.org/

Or contact ojs@scirp.org 